\title{
Turbulent heat transfer as a control of platelet ice growth in supercooled under-ice ocean boundary layers
}

\author{
Miles G. McPhee ${ }^{1}$, Craig L. Stevens ${ }^{2,3}$, Inga J. Smith ${ }^{4}$, and Natalie J. Robinson ${ }^{2}$ \\ ${ }^{1}$ McPhee Research Company, Naches, Washington, USA \\ ${ }^{2}$ National Institute for Water and Atmospheric Research (NIWA), Greta Point, Wellington, New Zealand \\ ${ }^{3}$ Department of Physics, University of Auckland, Auckland, New Zealand \\ ${ }^{4}$ Department of Physics, University of Otago, Dunedin, New Zealand \\ Correspondence to: Craig L. Stevens (c.stevens@niwa.co.nz)
}

Received: 15 September 2015 - Published in Ocean Sci. Discuss.: 17 November 2015

Revised: 14 February 2016 - Accepted: 15 March 2016 - Published: 6 April 2016

\begin{abstract}
Late winter measurements of turbulent quantities in tidally modulated flow under land-fast sea ice near the Erebus Glacier Tongue, McMurdo Sound, Antarctica, identified processes that influence growth at the interface of an ice surface in contact with supercooled seawater. The data show that turbulent heat exchange at the ocean-ice boundary is characterized by the product of friction velocity and (negative) water temperature departure from freezing, analogous to similar results for moderate melting rates in seawater above freezing. Platelet ice growth appears to increase the hydraulic roughness (drag) of fast ice compared with undeformed fast ice without platelets. Platelet growth in supercooled water under thick ice appears to be rate-limited by turbulent heat transfer and that this is a significant factor to be considered in mass transfer at the underside of ice shelves and sea ice in the vicinity of ice shelves.
\end{abstract}

\section{Introduction}

In addition to seaward advection, calving and basal melting, the distribution of mass in ice shelves depends on the socalled ice pump (Lewis and Perkin, 1986). By this mechanism, water warmer than the in situ freezing point temperature, typically High-Salinity Shelf Water entering the undershelf cavity, encounters glacial ice at, or near, the grounding line. The local cooling and freshening by basal melting (Fig. 1) of the ice shelf underside happens at high local pressure. The resultant buoyant water circulates to lowerpressure regions as the glacier base thins toward the termi- nus, and in the process may become supercooled relative to its in situ pressure (Foldvik and Kvinge, 1974). Supercooled water can then deposit ice by direct growth of ice crystals attached at the ice underside, or by upward migration of frazil crystals suspended by turbulence in the water (Dieckmann et al., 1986). In this way, fresh glacial ice near the grounding line can be transformed to marine ice (Langhorne, 2008). Evidence from icebergs (Kipfstuhl et al., 1992), borehole (Craven et al., 2005) and radar studies (Engelhardt and Determann, 1987; Robin et al., 1983; Holland et al., 2009) indicate that marine ice can reach appreciable thicknesses, and that the ice pump is active under shelves where the water entering the cavity is near freezing.

Formation of marine ice (Fig. 1) under ice shelves is difficult to observe directly (Craven et al., 2005), but similar effects are readily observed beneath nearby sea ice where it is called platelet ice (e.g. Robinson et al., 2014; Hughes et al., 2014; Hoppmann et al., 2015; Langhorne et al., 2015). For example in McMurdo Sound, Antarctica, sea ice crystals that have formed in supercooled water have been observed and reported since the British National Antarctic (Discovery) Expedition of 1901-1904 (Hodgson, 1907) and the British Antarctic (Terra Nova) Expedition of 1910-1913 (Wright and Priestley, 1922). Crystals observed in McMurdo Sound have reported to be up to $250 \mathrm{~mm}$ in diameter (Robinson et al., 2014; Smith et al., 2001). In part because of their size and aspect ratio, and since turbulent suspension is not a direct driver, these crystals are identified as "platelet ice". They have been observed attached to the underside of sea ice (Gow et al., 1998), often forming layers 2-3 m thick (Dayton et al., 


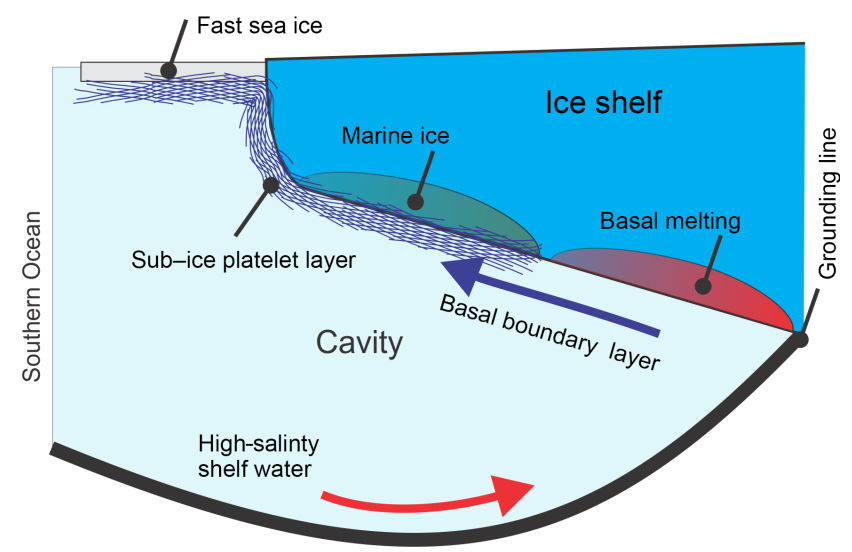

Figure 1. Ice pump showing High-Salinity Shelf Water (HSSW) flowing in at the base of an ice shelf cavity, commencing basal melting at, or around, the grounding line. This buoyant meltwater flows upwards and outwards in a basal boundary layer. An associated subice platelet layer supports ice growth through freezing into marine ice and sub-ice platelet layer beneath fast sea ice.

1969) and in some places as much as $8 \mathrm{~m}$ thick (Hughes et al., 2014). Platelet ice crystals have been observed to become incorporated into the sea ice by subsequent congelation growth (Jeffries et al., 1993).

The presence of supercooled water measured below sea ice (Lewis and Perkin, 1985; Smith et al., 2001), and the abundance of platelet ice, has been linked to locations of observed supercooling (Crocker and Wadhams, 1989) and to the ocean currents from beneath the ice shelf (Leonard et al., 2011; Fer et al., 2012). Evidence of this link is provided by the thicker accumulations of platelet ice (i.e. a sub-ice platelet layer, Fig. 1) found on the western side of McMurdo Sound (Dempsey et al., 2010; Hughes et al., 2014; Robinson et al., 2014), compared to that on the east (Gow et al., 1998; Jeffries et al., 1993; Dempsey et al., 2010) where platelet ice only starts to form in late winter (Paige, 1966). Leonard et al. (2006) and Mahoney et al. (2011) reported acoustic and video evidence that platelet ice crystals begin as small crystals $(2-20 \mathrm{~mm})$ that become larger once attached to the sea ice cover above.

Based on heat and mass balance measurements within the ice column, the residual oceanic heat flux associated with incorporated platelet ice has been reported as negative (i.e. heat moves downwards into the ocean) by several authors (Gough et al., 2012; Purdie et al., 2006; Smith et al., 2012, 2015) with values of $-30 \mathrm{~W} \mathrm{~m}^{-2}$ or more reported (Purdie et al., 2006; Smith et al., 2001; Langhorne et al., 2015). Smith et al. (2001) noted that forced convection was needed to account for the amount of platelet ice observed in McMurdo Sound, and Smith et al. (2001) and Stevens et al. (2009) estimated kinematic eddy viscosities of $2 \times 10^{-5}$ and $5 \times 10^{-4} \mathrm{~m}^{2} \mathrm{~s}^{-1}$, respectively, in supercooled water in McMurdo Sound. Smith et al. (2012) observed episodic growth of individual platelet ice crystals, with periods of growth at least an order of magnitude faster than the growth of the bulk sea ice. They suggested that variable currents were responsible for the episodic nature of the crystal growth. The appearance of these supercooling-induced crystals is not limited to the western margin of the Ross Ice Shelf, with observations made in other cold-cavity systems sampled to date (Dieckmann et al., 1986; Craven et al., 2014; Hoppmann et al., 2015; Langhorne et al., 2015).

The present work seeks to answer the questions (i) if and how the growth of platelet ice at a supercooled ice-ocean interface impacts the physical characteristics of the interface, including hydraulic roughness and the rate of heat transfer in the water column, and (ii) what feedback might exist. Direct turbulence measurements make this possible by enabling characterization of the boundary layer and direct measurement of heat fluxes. This facilitates improved parameterization of exchange processes in terms of mean quantities and will enhance the modelling of the ice-pump deposition phase in ice shelf cavities (Gwyther et al., 2015) as well as estimation of the spatial envelope of sea ice growth influenced by these cavities (Langhorne et al., 2015).

\section{Methods}

\subsection{Field camp and instrumentation}

In October and November 2010, the New Zealand National Institute of Water and Atmospheric Research (NIWA) established a temporary station, Erebus Field Camp (EFC), on fast (immobile) sea ice near Erebus Glacier tongue (EGT) in McMurdo Sound, Antarctica. The general layout of EFC and its location relative to nearby geographic features is described by Stevens et al. $(2014,2011)$ and shown in Fig. 2. The experiments took place prior to the 2012 calving that substantially reduced the length of the glacier tongue (Stevens et al., 2014). Included in the deployment was instrumentation designed to accurately measure current, temperature and salinity in tidal flow beneath the stationary sea ice, at a resolution sufficiently small to enable turbulent fluxes of momentum, heat and salt to be quantified.

A top-mounted mooring was deployed in $350 \mathrm{~m}$ of water, $2.5 \mathrm{~km}$ to the southwest of the EFC at $77^{\circ} 42.7730 \mathrm{~S}$, $166^{\circ} 21.4350 \mathrm{E}$, spanning the period in question. This mooring contained three Aanderaa RCM-9 units coupled with SBE 37 Microcat temperature, salinity and pressure recorders (Sea-Bird Electronics, USA). The current meterMicrocat pairs were located at depths of 50, 150 and $300 \mathrm{~m}$. Upon recovery of the mooring it was found that the line had lifted sufficiently so that the top $10 \mathrm{~m}$ had frozen into the growing sub-ice platelet layer. This has been encountered previously on instrument deployments when the buoyancy force from platelet accretion on mooring lines had overwhelmed the mooring ballast. The remote nature of the field 


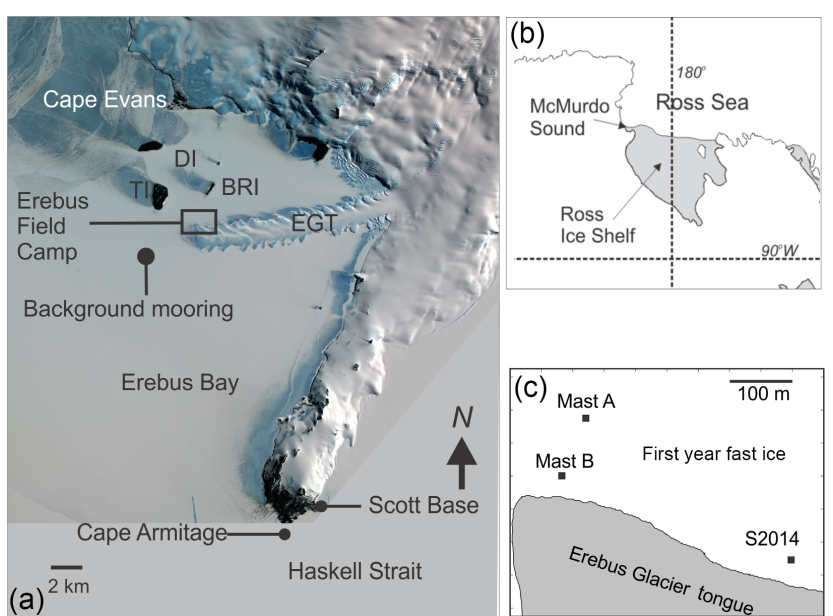

Figure 2. (a) Southwest McMurdo Sound image from ASTER (Advanced Spaceborne Thermal Emission and Reflection Radiometer) satellite image of southeast McMurdo Sound including the Erebus Glacier tongue (EGT), the Dellbridge Islands (DI), Erebus Bay, Cape Evans, Cape Armitage, Haskell Strait, Scott Base, background mooring and the Erebus Field Camp. The Dellbridge Islands include Tent Island (TI) and Big Razorback Island (BRI). (b) The McMurdo Sound region, Antarctica, in the context of the Ross Ice Shelf and the Ross Sea, (c) Erebus Field Camp locale showing the turbulence mast locations relative to the edge of EGT.

camp meant it was not possible to deploy very heavy ballast blocks.

Flux measurements near the ice-ocean interface were made with turbulence instrument clusters (TICs), each comprising an acoustic Doppler velocimeter (Sontek ADVOcean, $5 \mathrm{MHz}$ ), mounted with its fixed sample volume in the same plane as a nearby Sea-Bird Electronics temperature (SBE 3F)-conductivity (SBE 4) pair. Conductivity measurements were supplemented by a dual electrode microstructure conductivity instrument (SBE 7). The velocity sensors have a resolution of $0.1 \mathrm{~cm} \mathrm{~s}^{-1}$ and an accuracy of $\pm 1 \%$ of measured velocity. The dynamic range of the conductivity signal is typically large relative to instrument sensitivity with an initial accuracy of $\pm 0.0003 \mathrm{~S} \mathrm{~m}^{-1}$. The thermometers have an initial accuracy of $\pm 0.001{ }^{\circ} \mathrm{C}$ and a stability $0.002^{\circ} \mathrm{C}_{\text {year }}{ }^{-1}$ typically along with a self-heating error $<0.0001^{\circ} \mathrm{C}$ in still water. Here, we assume a working accuracy for the temperature sensors of $5 \mathrm{mK}$. TICs configured as above have been deployed under ice during several previous projects (McPhee, 2008a; McPhee et al., 2008, 2013; Sirevaag et al., 2010) and shown to measure well into the inertial subrange of the turbulent kinetic energy spectrum, hence adequately capturing the covariance of vector and scalar variables in turbulent flows.

The TICs were deployed on separate suspended masts (Fig. 2) under fast sea ice with $2.15 \mathrm{~m}$ in initial ice thickness starting with day of year (DOY) 298 and a thin layer ( $\sim 10 \mathrm{~cm}$, thick compared to observations described elsewhere, e.g. Robinson et al., 2014) of platelets. Mast A in- cluded two TICs mounted 1 and $3 \mathrm{~m}$ below the ice on a fixed mast suspended through a $1 \mathrm{~m}$ diameter hole, located about $140 \mathrm{~m}$ from the edge of EGT. Mast B, located closer $(40 \mathrm{~m})$ to the glacier tongue, included two TICs mounted $4 \mathrm{~m}$ apart on a rigid mast that could be lowered by cable to depths up to $70 \mathrm{~m}$.

\subsection{Turbulence analysis}

Time series of three velocity components, temperature and salinity derived from temperature and conductivity were segmented into $15 \mathrm{~min}$ realizations for calculating turbulence statistics, including the rate of dissipation of turbulent kinetic energy $\varepsilon$, following the method described by McPhee (2008a). Currents averaged over each realization were rotated into a reference frame such that mean vertical and cross-stream horizontal components vanished, from which the velocity perturbation components were resolved $(u, v$ and $w)$. Linear trends were then removed, then "areapreserving" (weighted) spectra were calculated and transformed to the wavenumber (spatial) domain under the frozen field hypothesis. Ice nucleation on instruments immersed in supercooled water significantly degraded their performance after just a few tidal cycles. This can affect both ADVs and conductivity sensors. We used the criteria identified in McPhee et al. (2013) to remove affected data. Ice accreting on the ADV hydrophones increased noise at higher frequencies, eventually leading to incorrect velocities. Consequently, we placed added emphasis on ensuring that turbulent spectra exhibited key elements including a peak in the areapreserving spectrum of vertical velocity variance and a reasonable fall off to the $-2 / 3$ slope in the $\log -\log$ representation of the area-preserving spectrum (McPhee, 1994, 2008a). Each 15 min spectrum was evaluated for a discernible peak in the area-preserving vertical velocity variance spectrum, and if found to be viable, was included in a $3 \mathrm{~h}$ grouping of realizations to determine mean statistics.

Friction speed, $u_{*}$, (the square root of kinematic Reynolds stress magnitude) was estimated by averaging covariance statistics, i.e.

$u_{*}=\left(\left\langle u^{\prime} w^{\prime}\right\rangle^{2}+\left\langle v^{\prime} w^{\prime}\right\rangle^{2}\right)^{1 / 4}$,

where we have invoked Taylor's frozen field hypothesis linking measurements in the time domain at a single location to ensemble statistics. After identifying the peak in each spectrum, a high-order polynomial was fitted to wavenumbers in its vicinity, which was then analysed to determine the wavenumber where the negative slope reached or exceeded two-thirds, taken as signifying spectral levels in the inertial subrange. The turbulent kinetic energy (TKE) dissipation rate was estimated from (see e.g. Tennekes and Lumley, 1972)

$\varepsilon^{2 / 3}=\frac{3}{4 \alpha_{\varepsilon}} S_{\mathrm{ww}}(k) k^{5 / 3}$, 


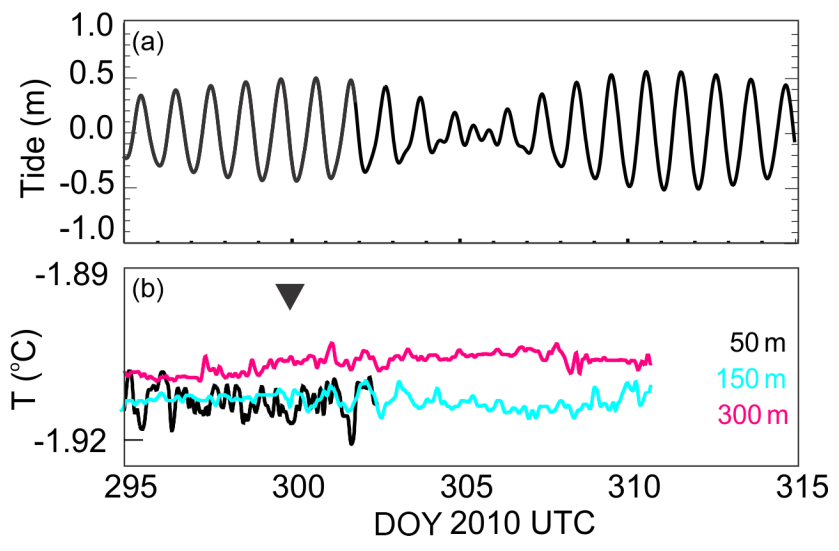

Figure 3. (a) Tidal elevation and (b) in situ temperatures from background mooring (shown in Fig. 2). The time of the present detailed observations are marked with the triangle in (b). The sensor at $50 \mathrm{~m}$ stopped early due to battery exhaustion.

where $S_{\mathrm{ww}}$ is the spectral density evaluated at angular wavenumber $k$, in the inertial subrange, and $\alpha_{\varepsilon}$ is the Kolmogorov constant for the along-stream spectrum (0.51).

By assuming that flow within $1 \mathrm{~m}$ of the boundary lies within the so-called surface layer, where stress is nearly constant and the velocity profile is logarithmic, then TKE production rate by current shear is

$P_{\mathrm{s}}=\tau \frac{\partial u}{\partial z}=\frac{u_{*}^{3}}{\kappa|z|}$,

where $\kappa$ is Kármán's constant (0.4). It is possible that buoyancy effects are also contributing to the turbulence and this is examined by comparing production and dissipation rates.

\section{Results}

The present data come from the "springs" period of the spring-neap tidal cycle (Fig. 3a) in order to experience the widest range of flow speeds, although the tidal effect is only weakly manifest in the far-field thermal structure (Fig. 3b). No data were retrieved from this far-field mooring at depths shallower than $50 \mathrm{~m}$ due to platelet growth effects. Indeed, as well as the incorporation of the upper $10 \mathrm{~m}$ of the instrumented mooring line into the growing sea ice, the mooring line itself was subject to ice accumuation-driven and buoyancy-driven rise of $8 \mathrm{~m}$ in a 50-day period although the lift was only around $1 \mathrm{~m}$ during the collection of the data in (Fig. 3). The $50 \mathrm{~m}$ data remain from around -1.91 to $-1.92^{\circ} \mathrm{C}$.

At the mast site, during the measurement period, profiles made with the mobile TIC Mast B indicated that the water column was isothermal to about $40 \mathrm{~m}$. In addition, data described in Stevens et al. (2014) from the same campaign support the contention that, to within $\pm 5 \mathrm{mK}$, the upper $40 \mathrm{~m}$
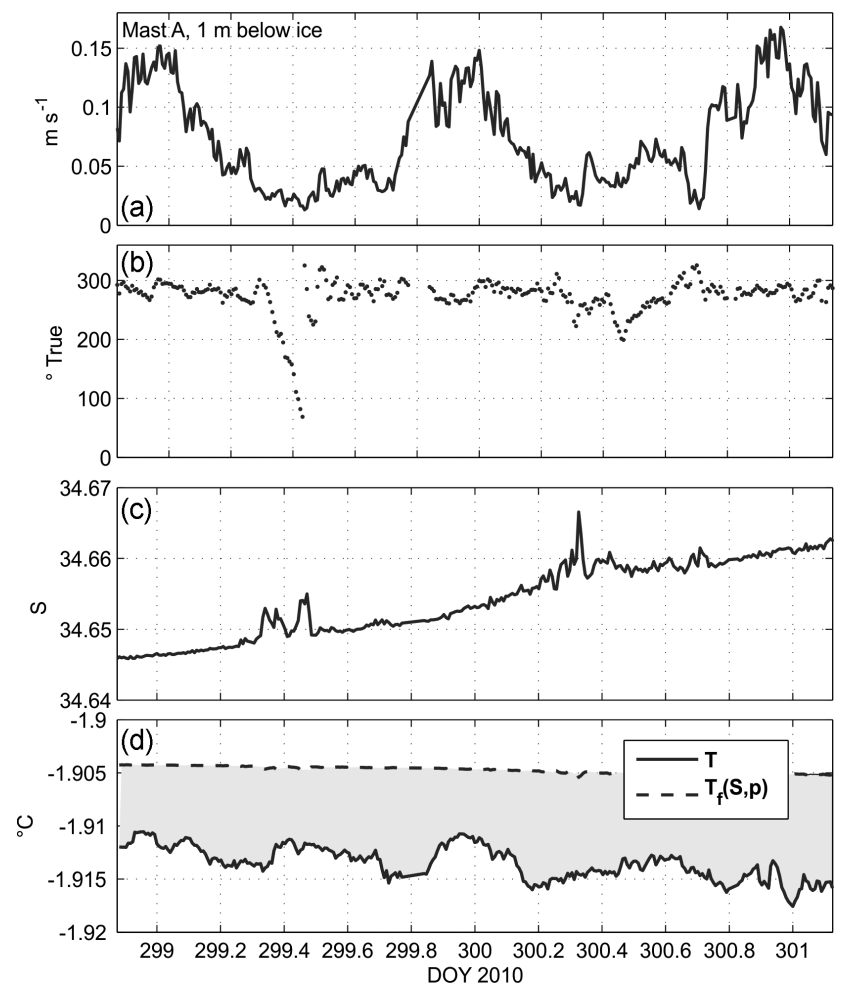

Figure 4. (a) Current speed at $1 \mathrm{~m}$ below the ice-ocean boundary from Mast A. (b) Current direction (bearing from true north). (c) Salinity $S$ (practical salinity scale). (d) Water temperature (solid) and water freezing temperature at $2 \mathrm{~m}$ depth (dashed).

was isothermal. The upper $15 \mathrm{~m}$ exhibited temperatures below the pressure-dependent freezing temperature, i.e. in situ supercooled. The growth of ice on the far-field mooring was corroborated by platelet growth on the cable suspending Mast B. At Mast A (TICs at 1 and $3 \mathrm{~m}$ below the ice undersurface) ice accretion on the instruments limited the duration of acceptable measurements to about two diurnal cycles $(\sim 60 \mathrm{~h})$ ending early (UTC) on DOY 301 . Shortly afterwards, Mast A was recovered, and thereafter Mast B was generally stationed below the supercooled zone at depths ranging from 18 to $62 \mathrm{~m}$, so as to minimize ice accretion. Here, we emphasize data from Mast A to address conditions near the horizontal fast ice-ocean interface.

Data recorded during spring tides provide the largest velocity range and also the largest horizontal advection of different water masses. Currents measured $1 \mathrm{~m}$ below the icewater boundary at Mast A from late on 25 October 2010 (DOY 298) to early on 28 October (Fig. 4a) show a significant tidal signal resulting in speeds up to around $0.15 \mathrm{~m} \mathrm{~s}^{-1}$. This is superimposed upon a steadier westward flow strong enough to prevent current reversal (Fig. 4b) either through flow rectification or regional circulation (Stevens et al., 2011, 2014). This was confirmed over a 10-day period beginning on DOY 300, where currents measured in the upper $60 \mathrm{~m}$ of the water column at the Mast B site ranged from 0.03 to 

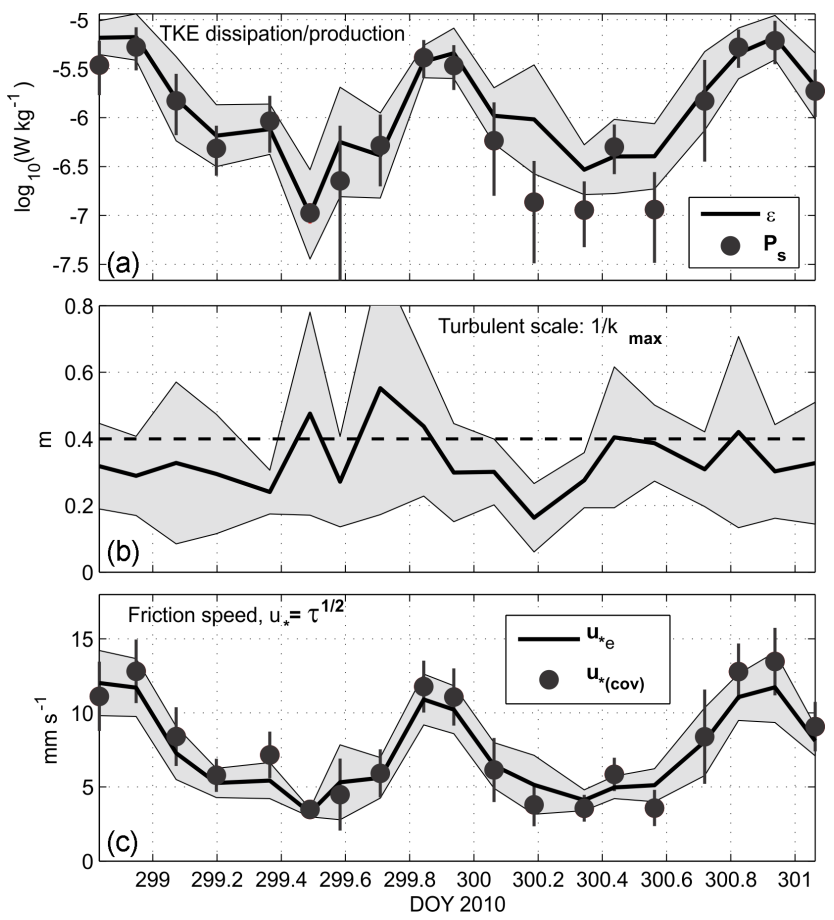

Figure 5. (a) Three-hour averages of turbulent kinetic energy dissipation rate (solid with shading showing \pm 1 standard deviation of the 15 min realizations in each average) and TKE production by shear (circles with standard deviation). (b) Turbulent length scale from the inverse wavenumber at $w$ variance spectral peaks. Dashed line indicates the "geometric" surface layer scale, $\kappa|z|$. (c) Independent estimates of friction speed from $w$ variance spectra (solid with shading) and from covariance statistics (circles with standard deviation bars).

$0.28 \mathrm{~m} \mathrm{~s}^{-1}$ westward (Stevens et al., 2014). Salinity shows a slowly increasing trend of around 0.0075 day $^{-1}$ that is interrupted briefly during low flows ("slack water") at highand low-tide (Fig. 4c). In near-freezing waters, salinity dominates buoyancy and so these perturbations are likely some form of propagating feature in the density structure. Certainly, the features in salinity at DOY 299.3-299.5 coincide with the directional change in Fig. 4b. Temperature measurements (Fig. 4d) on the other hand do not have obvious signatures connected to the flow. This is not uncommon at these temperatures where there is almost no thermal contribution to density. The record shows that water $1 \mathrm{~m}$ below the ice remained, on average, $8.7 \mathrm{mK}$ below freezing. The salinity trend's influence on the freezing point is apparent in Fig. 4d. This trend is largely mirrored in the measured temperature.

Consideration of the turbulent properties in the measurement volume indicates that the $3 \mathrm{~h}$ average estimates of rate of dissipation of turbulent kinetic energy $\varepsilon$ compares closely to the production $P_{\mathrm{s}}$ (Fig. 5a). The only departure from this is for a slack water low-flow period (DOY 300.2300.6) when the production estimate drops significantly below the dissipation rate estimate. Under-ice measurements
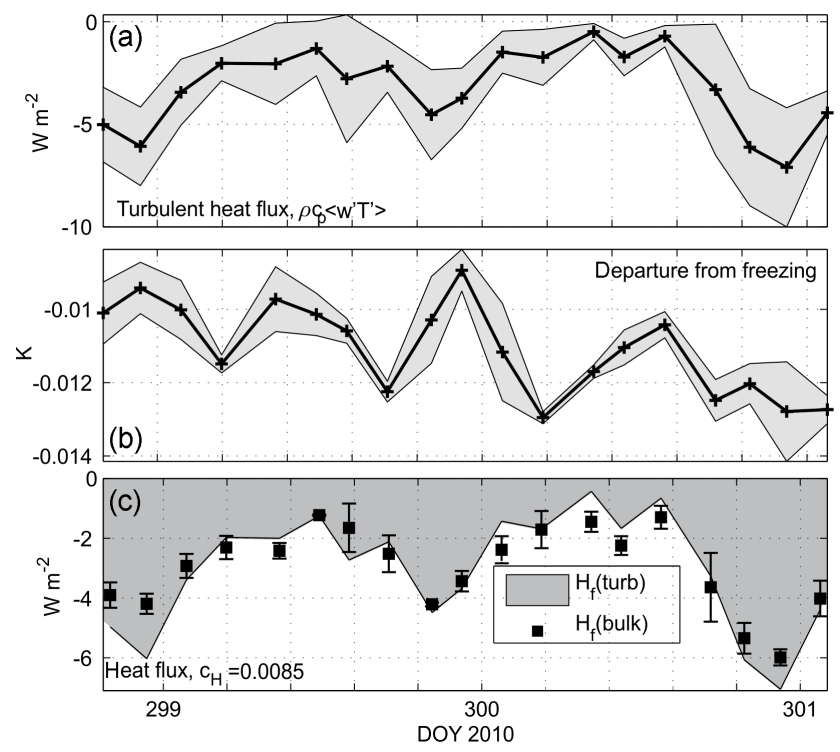

Figure 6. (a) Three-hour averages of turbulent heat flux, solid with standard deviation shading. (b) Departure of temperature from in situ freezing point temperature. (c) Comparison showing measured heat flux (shaded) with bulk estimates based on the product of $u_{*}$ and $\Delta T$ using the transfer coefficient identified using Eq. (6).

have shown close correspondence between the dominant turbulence length scale and the inverse of the angular wavenumber at the peak of the vertical velocity variance spectrum, i.e. $\lambda=c_{\lambda} / k_{\max }$, where $c_{\lambda}$ is a constant of order unity (McPhee, 2008a; McPhee and Martinson, 1994). A time series of $\lambda$ is compared with the geometric (surface layer) scale $\kappa|z|$ in Fig. $5 b$ which one would expect to be a limiting scale on the turbulent eddies. The inverse peak wavenumber turbulence lengthscale sits mostly beneath the geometric scale.

When TKE production and dissipation rates are comparable, as suggested by Fig. 5a, the following steady, horizontally homogeneous TKE equation provides an independent estimate of friction speed based exclusively on characteristics of the vertical velocity variance spectrum:

$u_{*}^{3}=\lambda \epsilon=\frac{c_{\lambda}}{k_{\max }} \epsilon$.

The virtually independent estimates of friction speed (Fig. 5c) agree well. This supports the hypothesis that buoyancy-induced turbulence is minimal in the present conditions.

The vertical turbulent heat flux can be estimated from

$H_{\mathrm{f}}=\rho c_{\mathrm{p}}\left\langle w^{\prime} T^{\prime}\right\rangle$,

where $\rho$ is water density and $c_{\mathrm{p}}$ is specific heat of seawater at constant pressure (Fig. 6a). Heat flux measurements derived in such a way (Fig. 6a) remain entirely negative with the standard deviation being around half the mean value. The heat flux follows a weakly diurnal pattern with broad similarity to 
$u_{*}$ (Fig. 5c). The implication then is that a bulk description may be useful as employed for moderate melt rates in water above freezing, so that

$H_{\mathrm{f}}=\rho c_{\mathrm{p}} c_{\mathrm{H}} u_{*} \Delta T$,

where $\Delta T=T-T_{\mathrm{f}}(S, p)$ is the departure from the freezing temperature. The $\Delta T$ (Fig. 6b), is semidiurnal in structure and so not particularly coupled with the diurnal cycle seen in the calculated and measured heat fluxes (Fig. 6a and c). The departure from the freezing point temperature also exhibits the trend of becoming larger (i.e. increasingly negative) with time during the observation period. The relationship can be restructured to solve for the transfer coefficient $c_{\mathrm{H}}$. Averaging the ratio from each of the acceptable $3 \mathrm{~h}$ averages results in $c_{\mathrm{H}}=0.0085$. Applying this average bulk transfer coefficient and comparing with the measured (Fig. 6c) indicates that the bulk approach does reasonably well. Notably, the diurnal cycle, while not apparent in the semidiurnal $\Delta T$, is sufficiently strongly manifest in the $u_{*}$.

\section{Discussion}

The questions posed in the introduction relate to how the supercooling and the modified roughness associated with the resulting crystals influence the heat flux. Equation (6) indicates that the problem, for a given temperature difference, can be reduced to a combination of the turbulent heat transfer coefficient $c_{\mathrm{H}}$ and the turbulent velocity scale. The $c_{\mathrm{H}}$ value found here $(0.0085)$ is not far different from values reported for basal heat exchange in above freezing water: e.g. $c_{\mathrm{H}}=0.0057$ for the year-long SHEBA project in the western Arctic (McPhee, 2008a); 0.0056 for first-year ice in the Weddell Gyre (McPhee et al., 1999). Furthermore, it almost matches the $c_{\mathrm{H}}=0.0084$ determined for rapid melting in the eastern Arctic (Sirevaag, 2009). This suggests any different behaviour in heat flux is due to the velocity structure induced by the roughness.

As identified by Gwyther et al. (2015), the roughness of the boundary affects growth in two ways. First, it influences heat transfer at the ice-ocean interface and second, it alters the mixing within, and entrainment into, the basal boundary layer (Fig. 1). While these authors note that sea ice is different to the underside of an ice shelf, it is likely that, at the boundary-layer scale, the presence of supercooled water and platelet ice crystals will generate similar effects in the two systems.

There is supercooled ice shelf water (ISW) water below the crystals, and these large crystals could not appear from the smaller ISW plume, because such large crystals would be sufficiently buoyant to leave the ISW plume (Jenkins and Bombosch, 1995; Smedsrud and Jenkins, 2004). The crystals require further in situ heat loss to grow to the large sizes observed. As the heat flux through the thick fast ice is small it indicates the ocean heat flux is the major driver of growth.
This is supported here as the ocean turbulent heat flux was negative (downward) throughout the entire measurement period (Fig. 6a). Sea ice in this region typically forms as congelation ice early in the growth season, then forms incorporated platelet ice towards the end of the growth season (e.g. Smith et al., 2001). Congelation ice grows when the latent heat released during phase change is conducted from the relatively warm ocean to the relatively cold atmosphere. In this context, relatively cold means below the freezing point temperature of seawater. Platelet ice crystal formation occurs in supercooled seawater and when this occurs near the ice-ocean boundary, the latent heat released can either be conducted upwards through the main ice column or transported downwards by turbulent heat flux into the ocean boundary layer. The latter process of negative oceanic heat flux does not occur for congelation ice because the ocean in that case is warmer than the freezing point temperature at the ice-ocean boundary.

There is a growing awareness of the ubiquity of such downward heat flux conditions in the vicinity of ice shelves (Robinson et al., 2014; Craven et al., 2015; Hoppmann et al., 2015). The resistance then imposed by a stationary ice cover influenced by such crystal growth on underlying boundary layer flow depends on the undersurface hydraulic roughness, $z_{0}$. For the conditions found at EGT (i.e. $P_{\mathrm{s}} \approx \varepsilon$, undeformed, relatively uniform underice surface), we expect the flow $1 \mathrm{~m}$ below the interface to follow the dimensionless shear equation

$\frac{\kappa|z|}{u_{*}} \frac{\partial u}{\partial z}=1$,

where $U$ is mean current speed. The integral of Eq. (7) yields a logarithmic velocity profile (the "law of the wall") where the integration constant is $\log z_{0}=-\kappa U / u_{*}$. For slow currents, the law of the wall is not necessarily valid at $1 \mathrm{~m}$ (McPhee, 2008b), so we evaluated $\log z_{0}$ for $3 \mathrm{~h}$ averages with current speeds $\geq 0.05 \mathrm{~m} \mathrm{~s}^{-1}$. For $U$ measured at $1 \mathrm{~m}$ (i.e. $\log 1=0)$ the average with standard deviation of the acceptable $3 \mathrm{~h}$ samples was

$\left\langle\log \left(z_{0}\right)\right\rangle=-3.95 \pm 0.30$.

The expected value for $z_{0}$ is thus about $19 \mathrm{~mm}$.

The observed $z_{0}$ identified here is larger than values obtained previously from measurements under undeformed fast ice without platelet accumulation, typically found to be nearly hydraulically smooth, with $z_{0} \sim 0.01 \mathrm{~mm}$ (Crawford et al., 1999; McPhee et al., 2008, 2013). It is comparable to values inferred for drifting, multiyear pack ice in the Arctic and western Weddell Sea: $\sim 40 \mathrm{~mm}$ (McPhee, 2008b; Shaw et al., 2009) and is considerably larger than first-year drifting ice near the centre of the Weddell Gyre, $\sim 1 \mathrm{~mm}$ (McPhee et al., 1999). 


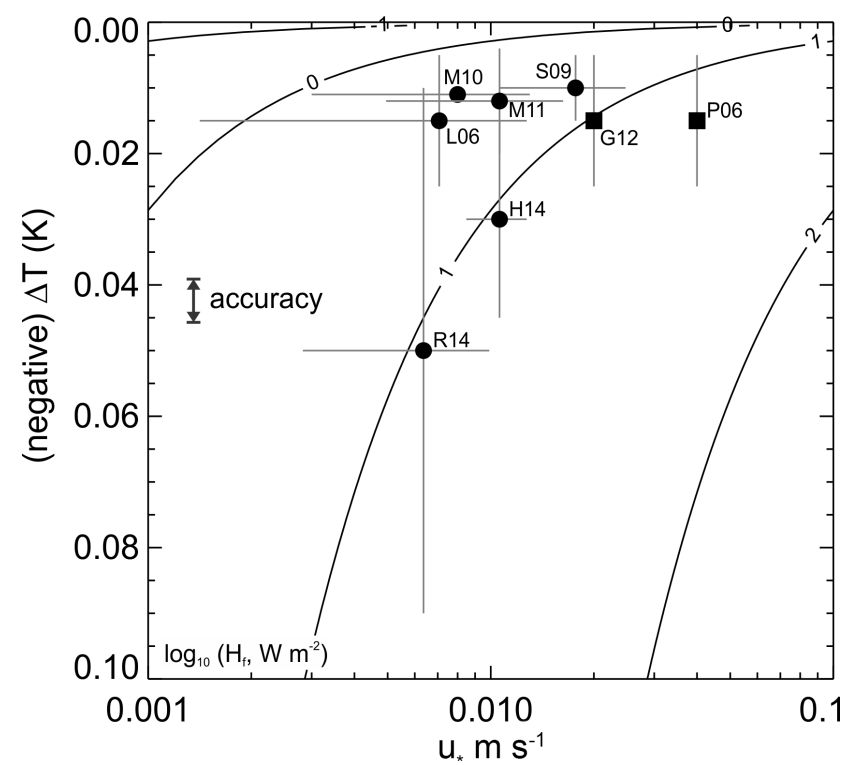

Figure 7. Contours of $\log _{10}$ of heat flux $H_{\mathrm{f}}$, as a function of friction speed $u_{*}$ and thermal driving $\Delta T$, for present $c_{\mathrm{H}}$ estimate. Contours describe Eq. (6). Circles are from measurements of $u_{*}$ and $\Delta T$, (L06, Leonard et al., 2006; S09, Stevens et al., 2009; M11, Mahoney et al., 2011; H14, Hughes et al., 2014; R14, Robinson et al., 2014; and M10, this study). The error bars represent degree of variability. The $u_{*}$ were either directly measured (i.e. M10) or inferred from flow $U$ using a drag coefficient whereby $u_{*}=\left(C_{\mathrm{d}}\right)^{1 / 2} U$. The squares are from observations inferring heat flux so that $u_{*}$ is calculated given observed $\Delta T$ (P06 Purdie et al., 2006; G12 Gough et al., 2012).

\section{Conclusions}

Our data show that turbulence-enhanced transfer of supercooled seawater can be the source of the negative heat flux measured within the ocean boundary layer during the present observations. Our results thus complement the negative ocean heat flux inferred from ice measurements by, e.g. Smith et al. (2012). In addition, Purdie et al. (2006) and Gough et al. (2012) estimated the amount of ice growth through negative oceanic heat flux (Fig. 7), which provides additional support for our contention. Furthermore, the downward ocean heat flux, which this work suggests depends on the product of friction speed and $\Delta T$, imposes a strong constraint on the rate of ice growth under stationary ice in supercooled water. This has significant implications for parameterization of basal boundary layers beneath both ice shelves and sea ice (Gwyther et al., 2015).

It is instructive to consider the heat flux distribution as a function of the $u_{*}$ and $\Delta T$ drivers (Fig. 7) as there is growing evidence that the presence of ice shelves produces values for both that are outside present expectations. The heat flux contours enable contextualization of existing results obtained either as measurements of $u_{*}$ and $\Delta T$ pairs or as a heat flux for a particular temperature condition. Parameterization in terms of $u_{*}$ suggests the use of a timescale is important. While heat flux is typically considered over daily, or longer, timescales so as to compare with seasonal ice growth, $u_{*}$ will be modulated primarily by tides as direct wind forcing is effectively absent in the present fast ice situation. This is especially important if there is some nonlinearity in the growth of more ice as the form of platelets influences $u_{*}$.

While the present short period of data saw variability around a factor of 6 in $H_{\mathrm{f}}$ (Fig. 6c) as the two drivers were largely decoupled, the contours (Fig. 7) show that, depending on the local turbulence conditions and degree of supercooling, this variability approaches 2 orders of magnitude. Extending this idea, Gwyther et al. (2015) presents a sensitivity analysis that suggest that the variability in $u_{*}$ through platelet modification of $C_{\mathrm{d}}$ might be as much as an order of magnitude. Future work to address this issue needs to focus on quantifying the combined influence of turbulence, thermally induced roughness and heat transfer.

Acknowledgements. The authors wish to thank Pat Langhorne for discussion and support. Tim Haskell, Brett Grant, Tim Stanton, Jim Stockel, Alex Forrest, Martin Doble and the staff of Scott Base are thanked for their support in the field. Metadata are lodged with Antarctica New Zealand. Two anonymous reviewers provided helpful comments. The work was funded by The New Zealand Royal Society-administered Marsden Fund, and USA NSF support to McPhee (ANT-0732804). I. J. Smith's involvement was supported through University of Otago Research Grant 111030. Logistic support was provided by Antarctica New Zealand and the USAP.

Edited by: M. Hoppema

\section{References}

Craven, M., Carsey, F., Behar, A., Matthews, J., Brand, R., Elcheikh, A., Hall, S., and Treverrow, A.: Borehole imagery of meteoric and marine ice layers in the Amery Ice Shelf, East Antarctica, J. Glaciol., 51, 75-84, doi:10.3189/172756505781829511, 2005.

Craven, M., Warner, R. C., Galton-Fenzi, B. K., HerraizBorreguero, L., Vogel, S. W., and Allison, I.: Platelet ice attachment to instrument strings beneath the Amery Ice Shelf, East Antarctica, J. Glaciol., 60, 383-393, doi:10.3189/2014JoG13J082, 2014.

Crawford, G., Padman L., and McPhee, M. G.: Turbulent mixing in Barrow Strait, Cont. Shelf Res., 19, 205-245, doi:10.1016/S0278-4343(98)00086-7, 1999.

Crocker, G. B. and Wadhams, P.: Modelling Antarctic fast-ice growth, J. Glaciol., 35, 3-8, 1989.

Dayton, P. K., Robilliard, G. A., and DeVries, A. L.: Anchor ice formation in McMurdo Sound, Antarctica, and its biological effects, Science, 163, 274-276, 1969.

Dempsey, D. E., Langhorne, P. J., Robinson, N. J., Williams, M. J. M., Haskell, T. G., and Frew, R. D.: Observation and modeling of platelet ice fabric in McMurdo 
Sound, Antarctica, J. Geophys. Res.-Oceans, 115, C01007, doi:10.1029/2008JC005264, 2010.

Dieckmann, G., Rohardt, G., Hellmer, H., and Kipfstuhl, J.: The occurrence of ice platelets at $250 \mathrm{~m}$ depth near the Filchner Ice Shelf and its significance for sea ice biology, Deep-Sea Res. A, 33, 141-148, 1986.

Engelhardt, H. and Determann, J.: Borehole evidence for a thick layer of basal ice in the central Ronne Ice Shelf, Nature, 327, 318-319, 1987.

Fer, I., Makinson, K., and Nicholls, K., Observations of thermohaline convection adjacent to Brunt Ice Shelf, J. Phys. Oceanogr., 42, 502-508, doi:10.1175/JPO-D-11-0211.1, 2012.

Foldvik, A. and Kvinge, T.: Conditional instability of sea water at the freezing point, Deep-Sea Res., 21, 169-174, doi:10.1016/0011-7471(74)90056-4, 1974.

Gough, A. J., Mahoney, A. R., Langhorne, P. J., Williams, M. J. M., Robinson, N. J., and Haskell, T. G.: Signatures of supercooling: McMurdo Sound platelet ice, J. Glaciol., 58, 38-50, doi:10.3189/2012JoG10J218, 2012.

Gow, A. J., Ackley, S., and Govoni, J. W.: Physical and structural properties of land-fast sea ice in McMurdo Sound, Antarctica, Antarct. Res. Ser., 74, 355-374, 1998.

Gwyther, D. E., Galton-Fenzi, B. K., Dinniman, M. S., Roberts, J. L., and Hunter, J. R.: The effect of basal friction on melting and freezing in ice shelf ocean models, Ocean Model., 95, 38-52, 2015.

Hodgson, T. V.: On collecting in Antarctic seas, in: Zoology and Botany. Volume III. British National Antarctic Expedition. 19011904, Trustees of the British Museum, London, UK, 1-10, 1907.

Holland, P. R., Corr, H. F. J., Vaughan, D. G., Jenkins, A., and Skvarca, P.: Marine ice in Larsen Ice Shelf, Geophys. Res. Lett., 36, L11604, doi:10.1029/2009GL038162, 2009.

Hoppmann, M., Nicolaus, M., Paul, S., Hunkeler, P. A., Heinemann, G., Willmes, S., Timmermann, R., Boebel, O., Schmidt, T., Kühnel, M., König-Langlo, G., and Gerdes, R.: Ice platelets below Weddell Sea landfast sea ice, Ann. Glaciol., 56, 175-190, 2015.

Hughes, K. G., Langhorne, P. J., Leonard, G. H., and Stevens, C. L.: Extension of an Ice Shelf Water plume model beneath sea ice with application in McMurdo Sound, Antarctica, J. Geophys. Res.-Oceans, 119, 8662-8687, doi:10.1002/2013JC009411, 2014.

Jeffries, M. O., Weeks, W. F., Shaw, R., and Morris, K.: Structural characteristics of congelation and platelet ice and their role in the development of Antarctic land-fast sea ice, J. Glaciol., 39, 223238, 1993.

Jenkins, A. and Bombosch A., Modeling the effects of frazil ice crystals on the dynamics and thermodynamics of the Ice Shelf Water plumes, J. Geophys. Res., 100, 6967-6981, doi:10.1029/94JC03227, 1995.

Kipfstuhl, J., Dieckmann, G., Oerter, H., Hellmer, H., and Graf, W.: The origin of green icebergs in Antarctica, J. Geophys. Res., 97, 20319-20324, 1992.

Langhorne, P.: Interactions between ocean, ice shelf, and sea ice, in: Proceedings of the 19th International Association of Hydraulic Engineering and Research Symposium on Ice. IAHR \& AIRH, Vancouver, Canada, 765-776, 2008.

Langhorne, P. J., Hughes, K. G., Gough, A. J., Smith, I. J., Williams, M. J. M., Robinson, N. J., Stevens, C. L., Rack, W., Price, D., Leonard, G. H., and Mahoney, A. R.: Observed platelet ice dis- tributions in Antarctic sea ice: An index for ocean-ice shelf heat flux, Geophys. Res. Lett., 42, 5442-5451. 2015.

Leonard, G. H., Purdie, C. R., Langhorne, P. J., Haskell, T. G., Williams, M. J. M., and Frew, R. D.:, Observations of platelet ice growth and oceanographic conditions during the winter of 2003 in McMurdo Sound, Antarctica, J. Geophys. Res.: Oceans, 111, C04012, doi:10.1029/2005JC002952, 2006.

Leonard, G. H., Langhorne, P. J., Williams, M. J. M., Vennell, R., Purdie, C. R., Dempsey, D. E., Haskell, T. G., and Frew, R. D.: Evolution of supercooling under coastal Antarctic sea ice during winter, Antarct. Sci., 23, 399-409, doi:10.1017/S0954102011000265, 2011.

Lewis, E. L. and Perkin, R. G.: The winter oceanography of McMurdo Sound, Antarctica, Antarct. Res. Ser., 43, 145-165, 1985.

Lewis, E. L. and Perkin, R. G.: Ice pumps and their rates, J. Geophys. Res., 91, 11756-11762, 1986.

Mahoney, A. R., Gough, A. J., Langhorne, P. J., Robinson, N. J., Stevens, C. L., Williams, M. J. M., and Haskell, T. G.: The seasonal appearance of ice shelf water in coastal Antarctica and its effect on sea ice growth, J. Geophys. Res.-Oceans, 116, C11032, doi:10.1029/2011JC007060, 2011.

McPhee, M. G.: On the turbulent mixing length in the oceanic boundary layer, J. Phys. Oceanogr., 24, 2014-2031, 1994.

McPhee, M. G.: Air-Ice-Ocean Interaction: Turbulent Ocean Boundary Layer Exchange Processes, 215 pp., Springer, New York, 2008a.

McPhee, M. G.: Physics of early summer ice/ocean exchanges in the western Weddell Sea during ISPOL, Deep-Sea Res. Pt. II, 55, 1075-1097, 2008b.

McPhee, M. G. and Martinson, D. G.: Turbulent mixing under drifting pack ice in the Weddell Sea, Science, 263, 218-221, 1994.

McPhee, M. G., Kottmeier, C., and Morison, J. H.: Ocean heat flux in the central Weddell Sea during winter, J. Phys. Oceanog., 29, 1166-1179, 1999.

McPhee, M. G., Morison, J. H., and Nilsen, F.: Revisiting heat and salt exchange at the ice-ocean interface: Ocean flux and modeling considerations, J. Geophys. Res.-Oceans, 113, C06014, doi:10.1029/2007JC004383, 2008.

McPhee, M. G., Skogseth, R., Nilsen, F., and Smedsrud, L. H.: Creation and tidal advection of a cold salinity front in Storfjorden: 2. Supercooling induced by turbulent mixing of cold water, J. Geophys. Res.-Oceans, 118, 3737-3751, doi:10.1002/jgrc.20261, 2013.

Paige, R. A.: Crystallographic studies of sea ice in McMurdo Sound, AntarcticaRep, US Naval Civil Engineering Laboratory, Port Hueneme, California, USA, 31 pp., 1966.

Purdie, C. R., Langhorne, P. J., Leonard, G. H., and Haskell, T. G.: Growth of first-year landfast Antarctic sea ice determined from winter temperature measurements, Ann. Glaciol., 44, 170-176, 2006.

Robin, G. D. Q., Doake, C. S. M., Kohnen, H., Crabtree, R. D., Jordan, S. R., and Möller, D.: Regime of the Filchner-Ronne ice shelves, Antarctica, Nature, 302, 582-586, 1983.

Robinson, N. J., Williams, M. J. M., Stevens, C. L., Langhorne, P. J., and Haskell, T. G.: Evolution of a supercooled Ice Shelf Water plume with an actively growing subice platelet matrix, J. Geophys. Res.-Oceans, 119, 3425-3446, doi:10.1002/2013JC009399, 2014. 
Shaw, W. J., Stanton, T. P., McPhee, M. G., Morison, J. H., and Martinson, D. G.: Role of the upper ocean in the energy budget of Arctic sea ice during SHEBA, J. Geophys. Res.-Oceans, 114, C06012, doi:10.1029/2008JC004991, 2009.

Sirevaag, A.: Turbulent exchange coefficients for the ice/ocean interface in case of rapid melting, Geophys. Res. Lett., 36, L04606, doi:10.1029/2008GL036587, 2009.

Sirevaag, A., McPhee, M. G., Morison, J. H., Shaw, W. J., and Stanton, T. P.: Wintertime mixed layer measurements at Maud Rise, Weddell Sea, J. Geophys. Res.-Oceans, 115, C02009, doi:10.1029/2008JC005141, 2010.

Smedsrud, L. H. and Jenkins, A.: Frazil ice formation in an ice shelf water plume, J. Geophys. Res., 109, C03025, doi:10.1029/2003JC001851, 2004.

Smith, I. J., Langhorne, P. J., Todahl, H. J., Haskell, T. G., Frew, R., and Vennell, R.: Platelets ice and the land-fast sea ice of McMurdo Sound, Antarctica, Ann. Glaciol., 33, 21-27, 2001.

Smith, I. J., Langhorne, P. J., Frew, R. D., Vennell, R., and Haskell, T. G.: Sea ice growth rates near ice shelves, Cold Reg. Sci. Technol., 83-84, 57-70, 2012.

Smith, I. J., Gough, A. J., Langhorne, P. J., Mahoney, A. R., Leonard, G. H., van Hale, R., Jendersie, S., and Haskell, T. G.: First-year land-fast Antarctic sea ice as an archive of ice shelf meltwater fluxes, Cold Reg. Sci. Technol., 113, 63-70, 2015.
Stevens, C. L., Robinson, N. J., Williams, M. J. M., and Haskell, T. G.: Observations of turbulence beneath sea ice in southern McMurdo Sound, Antarctica, Ocean Sci., 5, 435-445, doi:10.5194/os-5-435-2009, 2009.

Stevens, C. L., Sirguey, P., Leonard, G. H., and Haskell, T. G.: Brief Communication "The 2013 Erebus Glacier Tongue calving event", The Cryosphere, 7, 1333-1337, doi:10.5194/tc-7-13332013, 2013.

Stevens, C. L., Stewart, C. L., Robinson, N. J., Williams, M. J. M., and Haskell, T. G.: Flow and mixing near a glacier tongue: a pilot study, Ocean Sci., 7, 293-304, doi:10.5194/os-7-293-2011, 2011.

Stevens, C. L., McPhee, M. G., Forrest, A. L., Leonard, G. H., Stanton, T., and Haskell, T. G.: The influence of an Antarctic glacier tongue on near-field ocean circulation and mixing, J. Geophys. Res.-Oceans, 119, 2344-2362, doi:10.1002/2013JC009070, 2014.

Tennekes, H. and Lumley, J. L. L: A first course in turbulence, MIT press, Cambridge, USA, London, UK, 320 pp., 1972.

Wright, C. S. and Priestley, R. E.: Glaciology - British (Terra Nova) Antarctic Expedition. 1910-1913, Harrison and Sons, London, UK, 1922. 